\title{
Bioassay using Daphnia magna Straus, 1820 to evaluate the sediment of Caí River (Rio Grande do Sul, Brazil)
}

\author{
Bioensaios utilizando Daphnia magna Straus, 1820 na \\ avaliação do sedimento do rio Caí (Rio Grande do Sul, Brasil)
}

Nara Regina Terra, Ilda Rosa Feiden, Fabiane Lucheta,

Silvana Pereira Gonçalves and Juliana Schons Gularte

Fundação Estadual de Proteção Ambiental Henrique Luis Roessler - FEPAM,

Av. Dr. Salvador França, 1707, Bairro Jardim Botânico, CEP 90690-000, Porto Alegre, RS, Brazil

e-mail: nara.terra@ufrgs.br; ilda.feiden@gmail.com; fabianelucheta@hotmail.com;

silvana.goncalves@acad.pucrs.br; julianaschons@hotmail.com

\begin{abstract}
Aim: The Caí River is one of the five that form the Guaiba Lake Hydrographic Basin. It is used for public water supply in the capital of Rio Grande do Sul; Methods: Sediment samples for toxicity test (21 days) with Daphnia magna were taken from four sites between the middle and upper reaches in this river from Mar./05 to June/09. Their quality is described based on the survival and reproduction responses of 440 test-organisms from the beginning of their lives (2-26 hours). Percentage survival, mean and total reproduction were calculated for this evaluation. Spearman correlation and Duncan Test were used to compare reproduction between sites and variation of this parameter statistically over time. Bacteriological, physical and chemical parameters in water samples collected during the period of the study were considered; Results: Acute toxicity was observed in $18 \%$ of the samples and chronic toxicity in $95 \%$, indicating the presence of small doses of environmental aggressors. Mortality and reproduction did not always follow the same trend, and it became clear that the reproductive activity was more sensitive when compared using contaminated samples. Duncan Test showed up to four clusters at sites $\mathrm{Ca} 070, \mathrm{Ca} 092$ and $\mathrm{Ca} 245$, indicating reproduction variation. A pattern of monthly rainfall distribution was not observed, nor was there a correlation between survival, reproduction and rainfall; Conclusions: Presence of low concentrations of xenobiotics was confirmed by physical, chemical, bacteriological and metal responses in water samples, besides a small effect on survival and constant change in reproductive activity in the organisms exposed to sediment samples. Long duration assays are more appropriate to evaluate environmental samples, since usually changes in ecosystem quality are tenuous and not detected by short tests. Caí River quality has improved, but further studies are needed to confirm this trend, and to follow the history of the area with a more detailed definition of the course characteristics and the most fragile sites in the region.
\end{abstract}

Keywords: cladoceran, bioassay, survival, reproduction, sediment.

Resumo: Objetivo: O rio Caí integra a Bacia Hidrográfica do Lago Guaíba que é utilizado para o abastecimento público de água da capital do Rio Grande do Sul; Métodos: Entre Mar./05 e Jun./09 foram amostrados quatro locais deste rio para avaliação da toxicidade do sedimento entre as regiôes média e superior, utilizando Daphnia magna, em testes de 21 dias. A qualidade foi descrita a partir da sobrevivência e reproduçáo, observadas em 440 organismos-teste, desde o início de suas vidas (2-26 horas). Para tanto foram calculadas a porcentagem de sobrevivência, média reprodutiva e reprodução total. Visando comparar estatisticamente a reproduçâo entre os locais e a variaçáo deste parâmetro no tempo, foram utilizados Teste de Duncan e Correlação de Spearman. Também foram considerados os parâmetros bacteriológicos, físicos e químicos em amostras de água realizadas no período de estudo; Resultados: Foi observada toxicidade aguda em $18 \%$ das amostras e toxicidade crônica em $95 \%$, indicando agressores ambientais em pequenas doses. Mortalidade e reprodução nem sempre seguiram a mesma tendência, ficando evidente a maior sensibilidade da atividade reprodutiva frente a contaminantes. O Teste de Duncan mostrou até quatro agrupamentos nos locais Ca070, Ca092 e Ca245, indicando variação na reprodução. Não foi observado padrão de distribuição para precipitação pluviométrica mensal nem correlação entre sobrevivência, reprodução e precipitação pluviométrica; Conclusóes: Foi confirmada a presença de xenobióticos 
em baixas concentraçôes através de análises físicas, químicas, bacteriológicas e de metais em amostras de água, além de pequena ação na sobrevivência e constante alteração na atividade reprodutiva nos organismos expostos às amostras de sedimento. Ensaios de longa duração são mais apropriados para avaliar amostras ambientais, pois normalmente as alteraçôes são tênues nestes ambientes e testes curtos não as detectam. Tem se observado recuperação na qualidade deste rio, no entanto estudos subseqüentes são necessários para confirmar esta tendência e traçar o histórico da área, definindo mais detalhadamente as características do curso e os locais mais frágeis da região.

Palavras-chave: cladóceros, bioensaios, sobrevivência, reprodução, sedimento.

\section{Introduction}

Anthropic activities interfere constantly in the balance of water bodies, changing local biocenosis and making it difficult for the ecosystem to recover naturally. The Caí River is used by several communities in the Rio Grande do Sul state and therefore it is a constant subject of study. Metallurgical industries, viticulture and tanneries, present in the area, release pollutants, such as nickel, copper and chromium, that besides being persistent are cumulative even when discharged in small doses, and very aggressive to living beings in high doses. Wang et al. (2007) observed a progressive reduction in the size of the second brood of Moina monogolica Daday, when exposed to $\mathrm{Cu}$. Meat packing industries in the region release other contaminants that cause oxygen depletion, and may also have aromatic compounds and salt that interfere in the biota. Domestic sewage, on the other hand, consisting mainly of organic matter, are rich in phosphorus and nitrogen, and can trigger blooms and DO depletion resulting in the asphyxiation of aquatic fauna. Runoff transporting sediment with a high concentration of $\mathrm{P}$ has been identified as one of the main routes of this element to surface water, constituting a threat to environmental quality due to its capacity to stimulate eutrophication in freshwater (Ballantine et al., 2009). The constant discharge of these materials can accumulate on river beds. Ankley et al. (1996) emphasized the importance of methods and models to predict the effects of sediment-associated contaminants on benthic communities. Gillis et al. (2005) suggest that exposure to the contaminated sediment may reduce the intake rate of Daphnia magna, a microcrustacean used in this study. Bioassays are tools that aim at environmental characterization and/or recovery. Since $D$. magna has the habit of grazing the substrate (Suedel et al., 1996) the species is appropriate for use in bioassays utilizing samples of metal-contaminated sediment. A record of the local polluting processes is supplied by this compartment by the accumulation of xenobiotics which may later return to the liquid layer of the river and enter the trophic system through remobilization. Contaminants from industrial, domestic and hospital sources, besides soil particles transported as a result of precipitations may reach the river bed. The increased river volume caused by precipitations is a crucial factor, since it remobilizes substances retained at the bottom, making them available and transporting them downstream. This can interfere significantly in environmental quality parameters. Uninterrupted sediment transport is seen in mountain rivers (Reis et al., 2010), such as the Caí, which have a smaller storage capacity. According to Reis et al. (2010) the mountain rivers, characteristically, respond rapidly to peaks of precipitation, provoking significant sediment load transports and associated pollutants, during short time periods.

The specie defined for the study is a dominant group of zooplankton in many aquatic systems, and could substantially influence the overall biogeochemical cycles of trace elements as a result of their grazing activities (Yu and Wang, 2002). This genus in a non-selective filter and the material added to the surface layer of sediment is ingested indiscriminately during the feeding process, and the species functions epibenthically (Burton Junior, 1992). D. magna has been considered the most sensitive animal for sediment assays, especially in the presence of metals (Nebeker et al., 1984). Response reproducibility and sensitivity, used by many researchers (Burton Junior, 1992; Terra et al., 2008), were determinant factors for the use of these cladocerans. In addition, D. magna retains metals, and transfers and bioaccumulates them via the trophic system (Barata et al., 2002).

The Caí River is constantly monitored for its effects on fauna because of its socioeconomic and environmental importance. Chronic long duration tests are used to look for these responses, since the reactions triggered in test-organisms may affect the environment. 
The purpose of this study is to evaluate the current situation of Caí River, and to compare the responses generated by work previously done in the same area (Terra et al., 2007), considering chemical, physical and environmental information, emphasizing biological responses such as survival and reproduction. Reproduction responds to environmental aggressions that had not been detected initially by the organism, or by physical and chemical parameters, and it is essential for the analysis of ecosystem quality, since often negative responses for mortality are accompanied by positive responses for reproductive deficiency (Nikunen, 1985).

\section{Material and Methods}

Reproduction and survival were observed in 440 Daphnia magna (Clone A) exposed to eleven samples of Caí River sediment collected with a Peterson grab between Mar./06 and June/09. The sites sampled are located between kilometers 245 and 70 from the river mouth. Chronic long duration tests (21 days) using cladocerans aged 2 to 26 hours at the beginning of the tests were performed to evaluate the sediment.

The points sampled are considered Class 2, according to Brazilian legislation (Brasil, 2005).
The sampling sites are named using the initials of the river name $(\mathrm{Ca})$ followed by the number of $\mathrm{km}$ from the mouth (Figure 1). Below are the main sources of pollution at each site:

Ca245 (S 29० 21' 46,5”; W 50' 31' 16,8”): livestock raising activities;

Ca136 (S 29० 19' 31"; W 51 10' 50”): meat packing, viticulture, industrial sewage and wastes;

Ca092 (S 29० 30' 18,8”; W 51 21' 36,4”): municipal sewage and metallurgical industry;

Ca070 (S 290 37' 48,6”'; W 51' 22' 45,6”): tanneries.

After sampling, the sediment was cooled $\left(4^{\circ} \mathrm{C}\right)$ and kept in the dark (Ingersoll et al., 1995), until the beginning of the tests, a period not longer than one month.

The environment was simulated with sediment and M4 medium at a ratio of 1:4 (v:v) (Burton Junior, 1992; Suedel et al., 1996; Terra et al., 2008). M4 medium was prepared as described in Elendt and Bias (1990). Laboratory film covered the beakers during the experiment, preventing contamination of the germinators and the possible loss of volatile substance, from the aliquoting of sediment to the end of the tests. Liquid medium was placed in test-beakers the day before the test-organisms were included, and from that

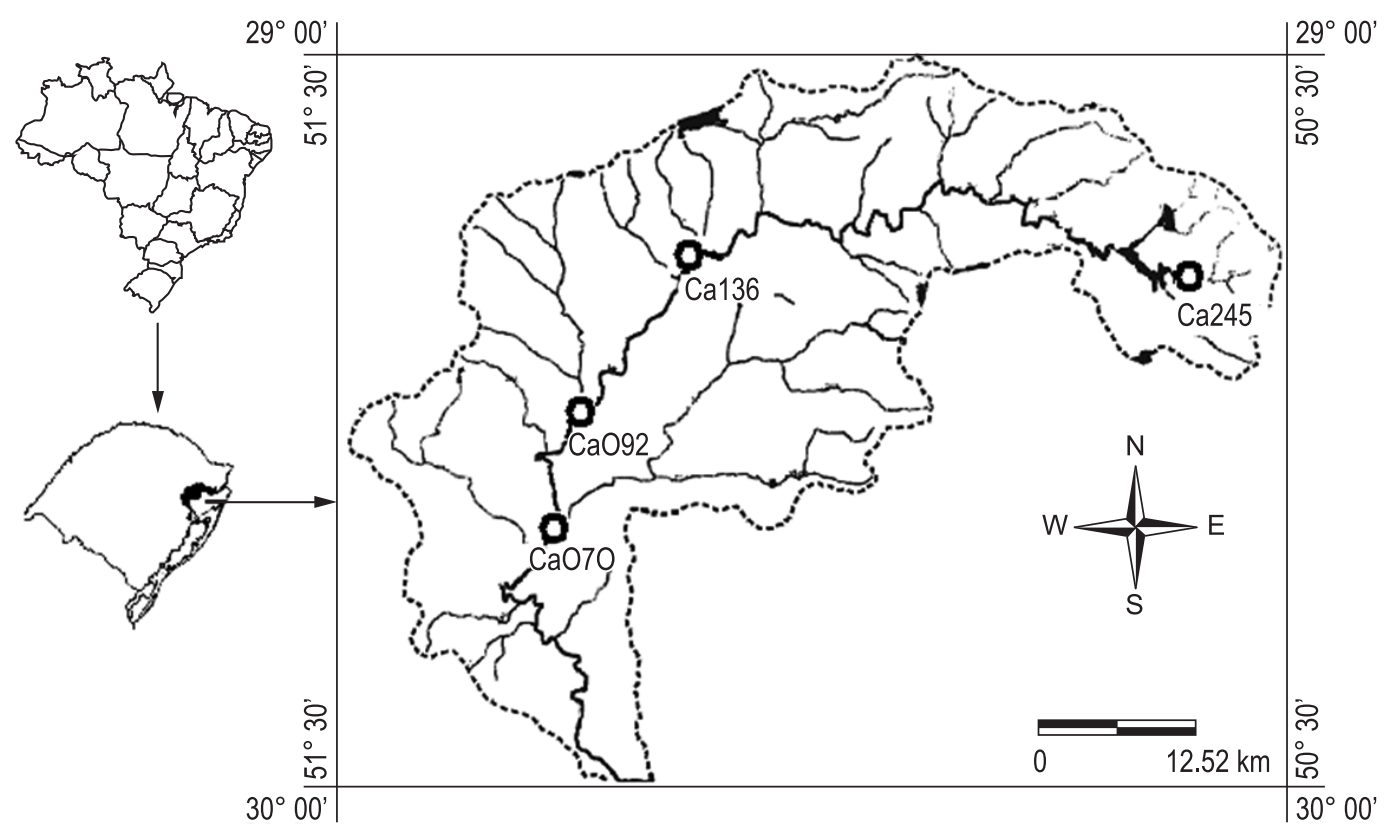

Figure 1. Location of the study site in Brazil, Rio Grande do Sul state, Caí River basin. Sites Ca245, Ca136, $\mathrm{Ca} 092$ and $\mathrm{Ca} 070$. 
point on they were acclimatized in a germinator. Homogeneous lots kept in M4 medium at a density of $25 \mathrm{org} / 1000 \mathrm{~mL}$ originated the test-organisms. All daphnids in this study were from the third or later brood presenting LC50-24 hours $=1.00 \pm$ $0.25 \mathrm{mg} \mathrm{K} \mathrm{Cr}_{2} \mathrm{O}_{7}$, calculated by the Trimmed Spearman-Karber Method (Hamilton et al., 1977).

Tests and lots were kept under the same conditions $\left(20^{\circ} \mathrm{C}+/-2^{\circ} \mathrm{C}\right.$; 16 hours light $/ 8$ hours dark), but in separate germinators to avoid contamination. The assays began with the inclusion of ten microcrustaceans per sample, individually distributed in beakers $(50 \mathrm{~mL})$. The distribution was random among all test-flasks and control-flasks.

Reproductive status and mortality (total lack of movement) were observed on Mondays, Wednesdays and Fridays. Whenever mortality was greater than $20 \%$, the site was identified as an inducer of acute toxicity, and when the reproductive mean per brood was less than 20 neonates, it was identified as an inducer of chronic toxicity. When the observations ended, the young were eliminated, the liquid medium was replaced by another recent one, the adult was reintroduced into the flask and fed. Desmodesmus subspicatus (Chodat, 1926) Hegewald and Schmidt, 2000 $\left(0.7 \mathrm{~mL} ; 10^{7}\right.$ cells. $\left.\mathrm{cm}^{-3}\right)$ and fermented fish chow enriched with biological yeast $(0.1 \mathrm{~mL})$ were used for feeding. The food prepared with fish chow and yeast followed the methodology recommended in NBR 12713 (ABNT, 2004). These amounts of food ensure the supply of nutrition until the next reading.

Duncan Test was applied to the statistical comparison of the reproductive data, comparing the period of study and the sites. Percentage survival and mean reproduction per brood was another focus of analysis. Spearman correlation between the biological parameters survival and reproduction and between precipitation and reproduction was applied in this study. The reproductive activity justifies further detailing of the analysis, because it expresses the chronic action exerted by the environment on the biota more frequently and more sensitively than acute action.

The responses of physico-chemical and bacteriological analyses in water samples, performed during the period of study, supported the analysis of biological information. The presence of total heavy metals at any time and concentration was considered because they were cumulative. The other parameters (Coliforms, Dissolved Oxygen; pH; P, N, Phenols index and Surfactants) were considered only at the time of sediment sampling. APHA (2005) was used for the analysis of heavy metals (Acid Digestion of Samples and Determination by Flame Atomic Absorption Spectrophotometry), phosphorus, nitrogen, phenols index and surfactants. The Multiple Tubes Test and Chromogenic Substrate Test techniques were used for coliforms. Dissolved Oxygen and $\mathrm{pH}$ were verified in loco by Oximeter and Potentiometer, respectively. Samples for heavy metal dosage were kept in glass flasks with a nominal capacity of $1000 \mathrm{~mL}$, containing $5 \mathrm{~mL}$ of nitric acid, while the samples for microbiological analyses were collected in a borosilicate flask with a wide mouth and a $100 \mathrm{~mL}$ capacity. Data in water samples are important because $D$. magna feeds by non-selective filtering (Suedel et al., 1996), extracting nutrients both from water and sediment. These parameter also cause environmental changes. Compartments that retain persistent xenobiotics with a possibility of remobilizing them are more effective in this type of study than those that evaluate the toxicity of the liquid layer, since they supply prior information in addition to that at the moment of sampling. However, anthropic actions trigger changes in the resident biota, in water as well as on the river beds, therefore both compartments indicate ecosystem quality.

Rainfall indices of the period of study, provided by Fundação Estadual de Pesquisa Agropecuária (FEPAGRO - State Foundation for Research on Agriculture and Livestock/data not published) and Defesa Civil (Civil Defense/www2.defesacivil. rs.gov.br/estatistica/pluviometro_consulta.asp) do Rio Grande do Sul were used to complement the study.

\section{Results}

Different sources of contamination define various levels of toxicity, like those found in the Caí River. They include navigation, industrial pollutants, domestic sewage and agricultural pesticides.

Acute toxicity for Daphnia magna was found in $18 \%$ of the samples, represented by an event at Ca070 (Mar./09) and at Ca092 (June/06), besides six at Ca245 (Mar./05; Mar./06, Sept./06, Dec./06; Dec./07; Mar./09) (Figure 2). Mean survival and standard deviation at each site can also be seen in the same figure.

Chronic toxicity, another approach evaluated, was more frequent, and detected in $95 \%$ of the assays. Chronic toxicity was only absent in one sediment sample collected at Ca136 (Mar./06) and Ca070 (Sept./06) (Figure 3). Standard deviation 


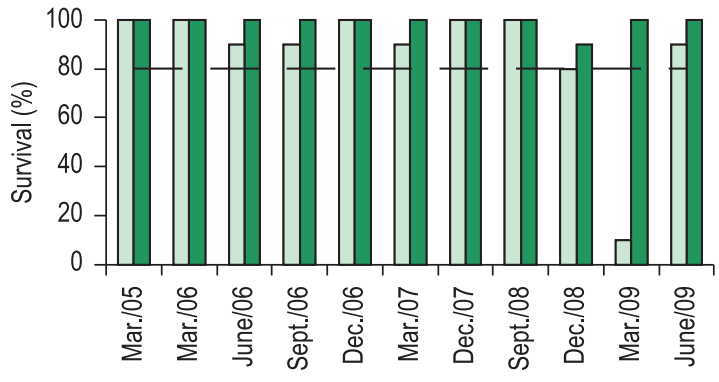

$\square$ Ca $070 \square$ Control — Limit $\bar{\chi}=8.6 ; \mathrm{SD}=2.6$

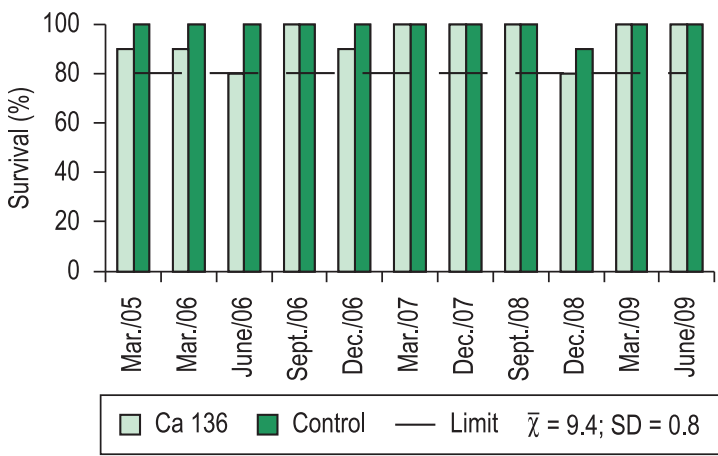

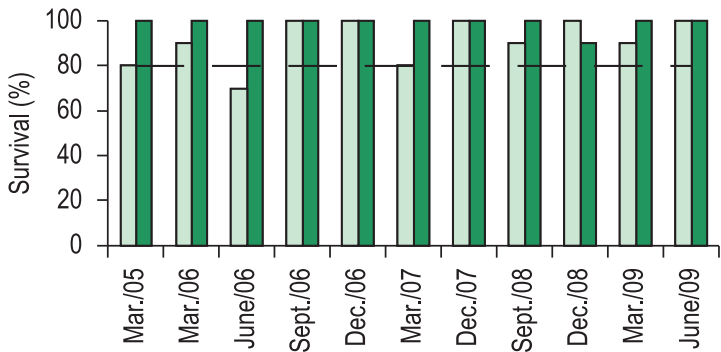

$\square$ Ca $092 \square$ Control - Limit $\bar{\chi}=9.1$; SD $=1.0$

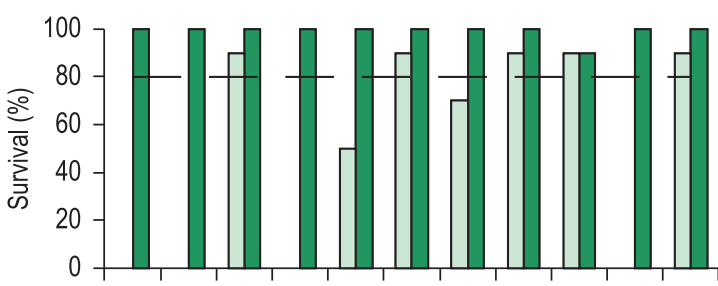

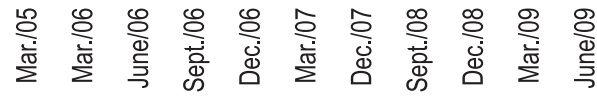

Ca $245 \square$ Control — Limit $\bar{\chi}=5.2 ; \mathrm{SD}=4.2$

Figure 2. Survival comparison, mean and standard deviation in Daphnia magna exposed to Caí River sediment samples, control group and expected survival from Mar./2005 to June/2009.

Ca 070

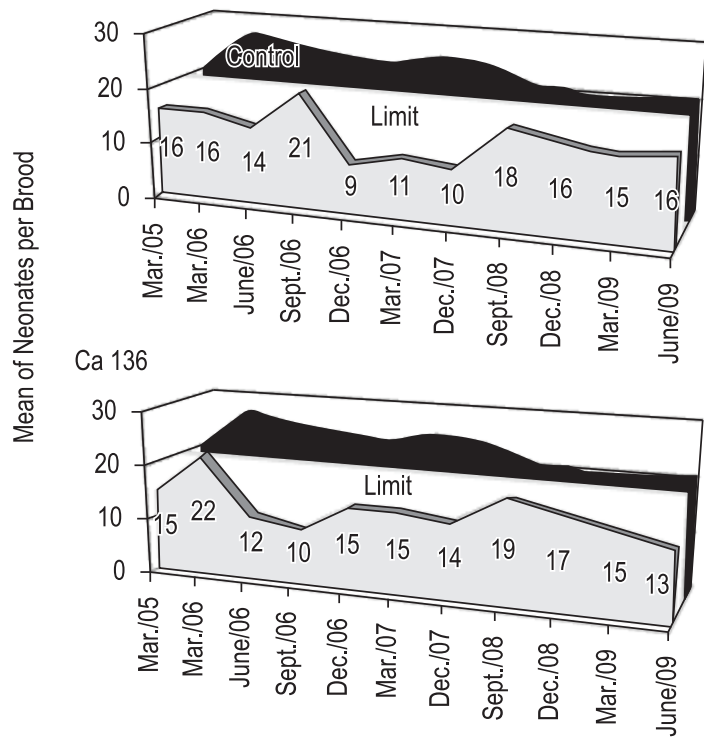

Ca 092

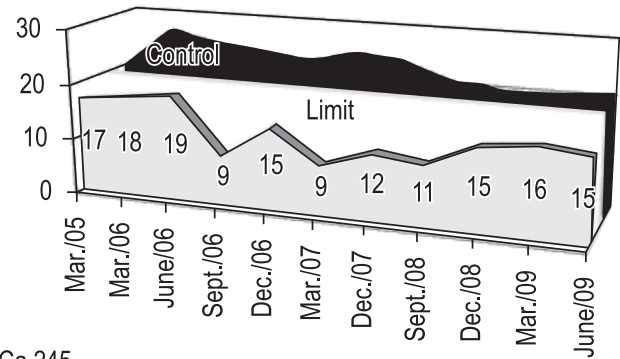

Ca 245

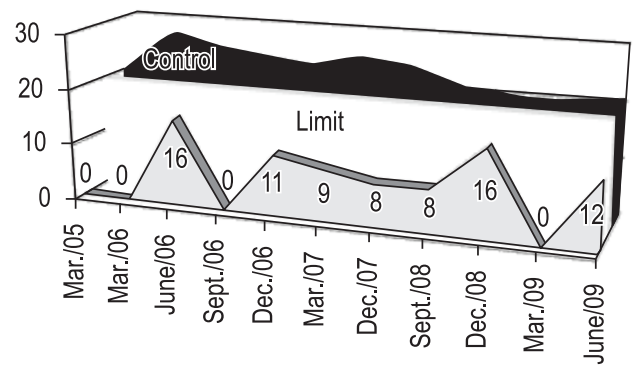

Figure 3. Mean number of neonates per Daphnia magna brood exposed to sediment samples from each site.

pointed to high variability in the number of neonates, especially at Ca245 (Figure 4).

Comparing the mean number of births between the points, per month sampled, applying the Duncan Test, three clusters were observed in Mar./06; Sept./06 and two in Mar./05; Dec./06;
Mar./07; Dec./07; Sept./07; Mar./09, while in June/06; Dec./08; June/09 the results were homogenous without forming groups (Figure 5).

Survival and reproduction were significant ( $p \leq 0.01$ ) only between the responses of site Ca245, when the Spearman correlation was applied. 
The Duncan Test $(\mathrm{p} \leq 0.01)$ identified the formation of groups when the interaction between factors site and month was analyzed, considering reproduction. Three groups were formed at Ca136 and four at the other sites (Table 1). Although some

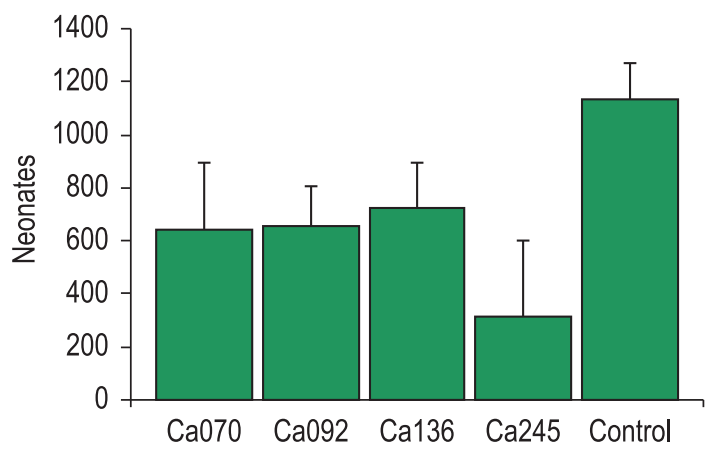

Figure 4. Mean number of neonates and standard deviation per point, considering the total number of births. months are similar: Sept./06 and 08; Dec./06 and 07; Mar./05 and 06 (Ca070); Mar./06 and 09; Dec./06, 07, 08 (Ca092); Mar./05, 07 and 09, June/06 and 09; Sept./06 and 08; Dec./06 and 07 (Ca136); Mar./ 05, 06 and 09; Dec./06 and 07 (Ca245), the Spearman correlation did not find significance between the results.

Heavy metals were detected in many samples, usually at values lower than the level determined by Brazilian legislation (Brasil, 2005). Of ten samplings analyzed for total chromium, whenever the metal was present the values were below the legally permissible level (four at $\mathrm{Ca} 070$; three at $\mathrm{Ca} 092$; four at $\mathrm{Ca} 136$ and three at $\mathrm{Ca} 245) . \mathrm{Cu}$ was researched in 14 water samples, and it was detected at $\mathrm{Ca} 070$ (three above, five below) $\mathrm{Ca} 092$ (five above, five below), Ca136 (seven above, two below) and Ca245 (one above, two below). Values below that allowed by Brazilian legislation were

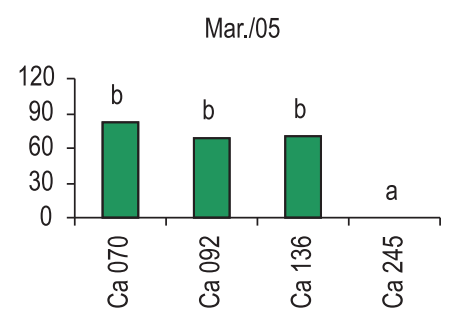

Sept./06

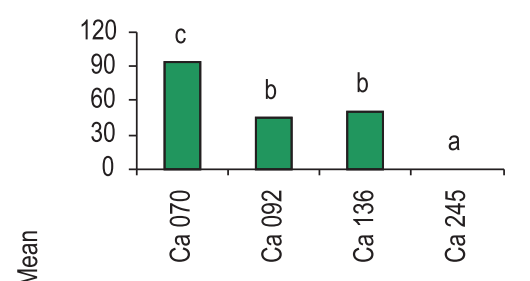

Dec./07

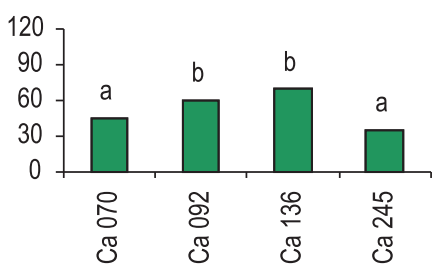

Mar./09

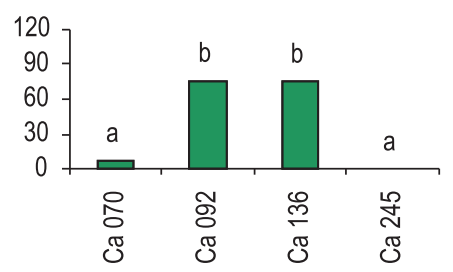

Mar./06

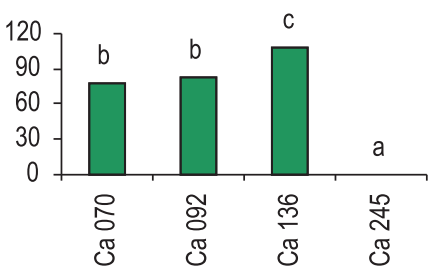

Dec.106

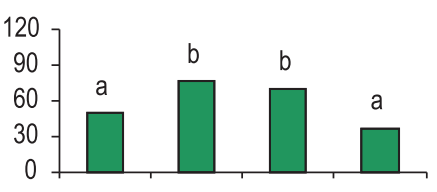

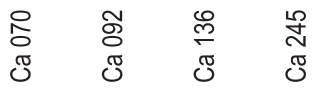

Sept./08

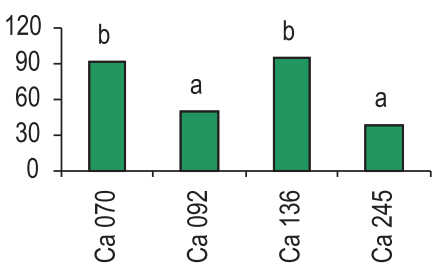

June/09

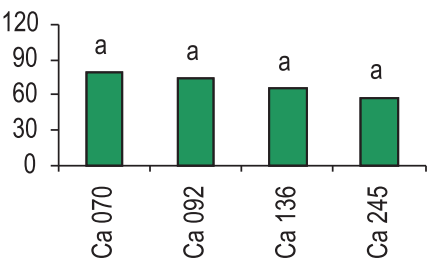

Figure 5. Mean number of neonates and comparison of the results between the sites using the Duncan Test. Same letter did not differ significantly by the LSD test $(\mathrm{p} \leq 0.01)$. 
Table 1. Variation of mean number of births at each site and indication of similar groups. Means followed by the same letter did not differ significantly by LSD test $(\mathrm{p} \leq 0.01)$.

\begin{tabular}{|c|c|c|c|c|c|c|c|c|c|c|c|}
\hline \multicolumn{3}{|c|}{ Site Ca070 } & \multicolumn{3}{|c|}{ Site $\mathrm{Ca} 092$} & \multicolumn{3}{|c|}{ Site Ca136 } & \multicolumn{3}{|c|}{ Site Ca245 } \\
\hline Month & Mean & C & Month & Mean & C & Month & Mean & C & Month & Mean & C \\
\hline Mar./09 & 7.3 & a & Mar./07 & 38.4 & $a$ & June/06 & 47.7 & $a$ & Mar./05 & 0 & $a$ \\
\hline Dec./07 & 44.9 & b & Sept./06 & 45.5 & $a, b$ & Sept./08 & 49.5 & a & Mar./06 & 0 & a \\
\hline Dec./06 & 49.5 & b & Sept./08 & 49.5 & $a, b, c$ & Sept./06 & 50.9 & a & Sept./06 & 0 & a \\
\hline Mar./07 & 50.7 & $b$ & Dec.107 & 60.2 & $a, b, c, d$ & June/09 & 65.3 & $a, b$ & Mar./09 & 0 & a \\
\hline June/06 & 63.6 & $b, c$ & Mar./05 & 69.1 & $b, c, d$ & Dec./07 & 69.3 & $a, b$ & Dec./07 & 35.1 & $b$ \\
\hline Dec./08 & 64.1 & $b, c$ & June/06 & 73.9 & $c, d$ & Dec./06 & 69.8 & $a, b$ & Dec./06 & 37.4 & $b$ \\
\hline Mar./06 & 78.2 & $c, d$ & June/09 & 74.5 & $c, d$ & Mar./05 & 70.1 & $a, b$ & Sept./08 & 37.9 & $b$ \\
\hline June/09 & 79.1 & $c, d$ & Dec./08 & 75.1 & $\mathrm{c}, \mathrm{d}$ & Mar./09 & 75.3 & $b$ & Mar./07 & 40.9 & $b, c$ \\
\hline Mar./05 & 82.5 & $c, d$ & Dec./06 & 75.7 & $\mathrm{c}, \mathrm{d}$ & Mar./07 & 76.7 & $b$ & June/09 & 57.8 & $c, d$ \\
\hline Sept./08 & 90.6 & d & Mar./09 & 76.0 & $c, d$ & Dec./08 & 86.2 & b & Dec./08 & 71.5 & d \\
\hline Sept./06 & 94.4 & $d$ & Mar./06 & 82.7 & $\mathrm{~d}$ & Mar./06 & 108.5 & c & June/06 & 72.9 & $d$ \\
\hline
\end{tabular}

Obs.: C = Comparison.

also detected for $\mathrm{Zn}$ at all sites. Ca092 was the only site where $\mathrm{Pb}$ (a single sample) was found, but the value was below the permissible level. This metal was researched in two samplings at $\mathrm{Ca} 070$ and in three at the other sites. $\mathrm{Hg}$ and $\mathrm{Ni}$ were looked at because they are potential pollutants in this area, but they were not detected. Ni can be found in effluents from metallurgical industry and according to Evens et al. (2009) it causes a significant reduction in the reproduction of $D$. magna in the 21-day test, while Nunes and Luiz (2006) report the presence of $\mathrm{Hg}$ in tannery effluents.

Of the physical, chemical and bacteriological parameters examined in water samples Escherichia coli presented values above the expected amount in Dec./08 at site Ca245. On the other hand, at Ca136 elevated values were detected for $E$. coli in the months of Mar./06, Mar./07, Sept./08 and Dec./08, $\mathrm{P}$ at all evaluations, Phenols in Mar./05, Dec./07 and Sept./08 and low content of DO in Mar./06. These parameters are related to local activities.

Similarly to the previous site, the results of water analysis at $\mathrm{Ca} 092$ were not in accordance with the legislation for E. coli (Mar./06, Sept./08, Dec./08), $\mathrm{P}$ in all samplings, phenols (Mar./06, Mar./07, Dec./07) besides turbidity (Mar./06).

Altered results were detected at site $\mathrm{Ca} 070$ for E. coli (Mar./06, Dec./07, Sept./08, Dec./08, Mar./09), $\mathrm{P}$ in all samplings, Phenols (Mar./07, Dec./07) e surfactants (Mar./06).

There was not found correlation between rainfall, survival and reproduction. The precipitation data showed the absence of a pattern in rainfall distribution between the points and seasons of the year. In Sept./08, Ca070 presented low precipitation (66 mm) compared to the others. In Dec./08 there was no precipitation at this site. At $\mathrm{Ca} 092$ and Ca136 the month with the lowest precipitation was Dec./08 (2.5 mm and $5.5 \mathrm{~mm}$, respectively). At $\mathrm{Ca} 245$ there was abundant precipitation during all seasons and the lowest value $(129 \mathrm{~mm})$ was recorded in June/09.

\section{Discussion}

The diversity of pollutants discharged into the Caí River from the source to the mouth compromises the water and bed quality of this river in many reaches, interfering in the recovery of some areas. The variability of responses seen in this study is due to the different sources of pollution, ranging from domestic sewage to industrial pollution, and they may be point occurrences or be transformed by the streams that form them. The total precipitation that occurred at the source (Ca245), during the time of this study, was more than three times the precipitation of the site furthest downstream (Ca070). It should be mentioned that when the water from the sources flows towards the mouth it transports sediment and pollutants.

Previously performed studies in the Cai River (Lemos et al., 1994; Terra et al, 2007; Terra and Feiden, 2008; Vargas et al., 2008) revealed the presence of areas highly polluted by different typologies and preserved areas.

Acute responses indicate the presence of point sources in the area of study, while changes in reproduction suggest sources that are already diluted and dispersed. Pollutants in general are transported by the river from the higher areas, close to the headwaters, to the lower course, concentrating greater diversity of pollutants at the mouth. Chen et al. (2006) emphasize that the 
influx of liquid into the river carries dissolved and particulate materials, which are major sources of contamination, and it also contributes to the water mixture. The same authors conclude by informing that the extent of the mixture or dissipation of influx is controlled primarily by the magnitude and density.

When cladocerans are exposed to samples of contaminated sediment they have a chronic or acute reaction. The reactions observed among the cladocerans used in this study are due to the feeding habits of this microcrustacean, which, according to Suedel et al. (1996) on reaching the age of $\geq 48$ hours actively grazes on sediment surfaces, releasing settled substances.

Areas with greater environmental involvement or point contamination are usually responsible for the presence of acute toxicity. An acute toxicity event was observed at $\mathrm{Ca} 070$ and another at $\mathrm{Ca} 092$. While the first site is influenced by tanneries, the second is close to metallurgical industries. An elevated level of mortality, however, occurred at $\mathrm{Ca} 245$ where the small activity with animal husbandry is the main source of pollution (Figure 2). A previous study (Terra et al., 2007) performed between Mar./01 and Dec./04, in the same area, showed seven cases of acute toxicity, three at Ca070 (Dec./01; Apr./03; Sept./04), one at Ca092 (Sept./04) and three at Ca245 (Mar./02; Apr./03; Dec./04). The natural characteristics of $\mathrm{Ca} 245$ are indicated in the same study (Terra et al., 2007) as responsible for an elevated mortality of test-organisms. High mortality was also observed in the present study, preferentially in the first week of life. Terra et al. (2007) reported that environments with stony sediment, as found at Ca245, are not appropriate for Daphnia magna. This site presents low available P content $\left(0.01 \mathrm{mg} . \mathrm{L}^{-1}\right)$, possibly as a result of the local geological formation (pebbles). He and Wang (2007) report greater loss of P in cladocerans during the molting process than in the production of neonates, thus, in the initial phase of development, when the growth rate is higher, requiring more $\mathrm{P}$. According to He and Wang (2008), when there is a deficiency of $\mathrm{P}$, successive changes occur during the food pre-absorption and absorption process and the time of passage of the particles through the gut in D. magna is increased, interfering in the efficiency of absorption and growth. The same authors also add that $\mathrm{P}$ is needed to produce viable eggs. Becker and Boersma (2005) say that D. magna needs P for survival, since it reallocates $\mathrm{P}$ to the reproduction and molting processes. On the other hand, the low
$\mathrm{Cu}$ content (ND in 11 of 14 samples) found at this point may also lead to the low development of cladocerans, since De Schamphelaere et al. (2004) point to the need for this metal, at minimal doses, to stimulate growth and reproduction of the species.

Considering survival, recovery of the environmental quality is seen at $\mathrm{Ca} 070$, while $\mathrm{Ca} 092$ has remained in the same conditions as before (Terra et al., 2007). Except for the site furthest upstream (Ca245), the others presented a similar number of survivors. While at $\mathrm{Ca} 070$, 95 individuals survived, at $\mathrm{Ca} 092,100$ individuals survived, at Ca136, 94 individuals, and at Ca245, only 54 , out of the total number of 110 cladocerans exposed at each point.

Mean survival varied among the sites, the lowest survival and highest standard deviation being at Ca245 ( $\bar{x}=5.2$; SD $=4.2)$ and the highest mean and lowest standard deviation at Ca136 ( $\bar{x}=9.4$; $\mathrm{SD}=0.8)$. The other sites presented $\bar{x}=8.6$; $\mathrm{SD}=2.6(\mathrm{Ca} 070)$ and $\bar{x}=9.1 ; \mathrm{SD}=1.0(\mathrm{Ca} 092)$. It can be said that the sites with the lowest standard deviation are more stable, without the presence of important point sources, and those with the highest mean survival are better conserved than the rest.

Responses to xenobiotics were observed through the reproductive process by the reduction in the number of neonates per brood, when only two of the 44 samples presented absence of chronic toxicity.

The highest mean number of neonates was seen at Ca136 (724.2) and the lowest at Ca245 (314.0). The other sites presented intermediate and close numbers: 640.8 (Ca070) and 655.1 (Ca092). The standard deviation, indicating the variation of births in relation to the mean, showed extreme values at the source and at the mouth (Ca245 $\mathrm{SD}=285.1 ; \mathrm{Ca} 070 \mathrm{SD}=252.4)$. At the other sites the values were similar (Ca136 SD = 171.8; Ca092 $\mathrm{SD}=147.8$ ), probably due to the same factors that interfered in survival.

Elevated values for $E$. coli $(2,400 \mathrm{MPN} / 100 \mathrm{~mL}$; CONAMA: 1,000 MPN/100 mL), P (0.953 mg.L $\mathrm{L}^{-1}$; CONAMA: $0.050 \mathrm{mg} . \mathrm{L}^{-1}$ ), Phenols (0.019 mg. $\mathrm{L}^{-1}$; CONAMA: $0.003 \mathrm{mg} . \mathrm{L}^{-1}$ ) and low DO content ( $4.5 \mathrm{mg} . \mathrm{L}^{-1}$; CONAMA: 5 mg. $\mathrm{L}^{-1}$ ), which are parameters related to local activities, were found at Ca136, but survival and reproduction were similar to the other months sampled. It can be suggested that since these parameters were not conservative they did not interfere in sediment quality.

Similarly to the previous site, at $\mathrm{Ca092}$, the results of analyses in water did not agree with the 
national legislation for $E$. coli $(2,400 \mathrm{MPN} / 100 \mathrm{~mL}$; CONAMA: 1,000 MPN/100 mL), P (0.424 mg.L-1 ; CONAMA: $\left.0.050 \mathrm{mg} . \mathrm{L}^{-1}\right)$, Phenols (0.056 mg. $\mathrm{L}^{-1}$; CONAMA: $\left.0.003 \mathrm{mg} . \mathrm{L}^{-1}\right)$ and also Turbidity (132 UNT; CONAMA: 100 UNT). Reproductive activity was only more inhibited when the presence of the phenols index was higher.

Both at $\mathrm{Ca} 070$ and at $\mathrm{Ca} 092$, low mean reproduction was observed when the phenols index was elevated (Ca070: $0.023 \mathrm{mg} . \mathrm{L}^{-1}$ (Mar./07); 0.01 mg. $\mathrm{L}^{-1}$ (Dec./07) and Ca092: $0.056 \mathrm{mg} . \mathrm{L}^{-1}$

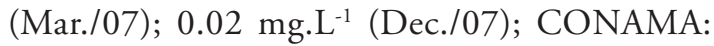
$\left.0.003 \mathrm{mg} \cdot \mathrm{L}^{-1}\right)$. Keen and Baillod (1985) and Kühn et al. (1989) report the toxicity of phenol and its byproducts for $D$. magna.

A Spearman correlation at Ca245 between survival and reproduction $(\mathrm{p} \leq 0.01)$ was expected since, although these two parameters are usually independent at sites where there is a high mortality, there is also interference in reproductive activity.

Sometimes a similarity was observed between the mean reproduction in the same months of different years (e.g.: Dec./06 and Dec./07), however they were not significant (Duncan Test: $\mathrm{p} \leq 0.01$ ) and it was not possible to establish the influence of seasonality. It is more likely that the results are related to current variation, effluent discharge or transport of contaminated soil.

The detection of heavy metals in many samples at values below the legally accepted levels must be considered, since these pollutants are cumulative. These pollutants are also available to zooplankton, and though this is a lower link in the trophic chain, it can reach man through the intake of fish and/or mollusks. Twining and Fisher (2004) report that metals have a stronger physiological effect when transmitted through the alimentary route than when they are biologically recycled.

The chromium present at doses lower than regulated in Brazilian legislation for Class 2 is one of the main contaminants in the leather tanning process. Therefore its presence is monitored in critical areas, such as $\mathrm{Ca} 070$, a site located in a region where there are many tanneries. Caí River tributaries, such as the Cadeia and Feitoria Rivers, which enter the Caí River at site Ca070, present a high concentration of chromium. According to Liu et al. (2002) the main pathway of $\mathrm{Cr}$ and $\mathrm{Zn}$ accumulation in zebrafish is zooplankton. Rodrigues and Formoso (2006) say that the Cr concentration increases in the sediment along these tributaries of the Caí River, reaching values of up to $1,031 \mu \mathrm{g}$ total $\mathrm{Cr} / \mathrm{g}$. These occurrences are attributed to the presence of tanneries. The absence of elevated levels of $\mathrm{Cr}$ at $\mathrm{Ca} 070$ may be the result of the dilution of contaminated water from the tributaries as they enter the Caí River which has a large volume of water and a strong current mixing its waters with those of the tributaries. Since metals are analyzed in water, it must be considered that the low values detected in liquid samples may interfere in the reproductive activity of the species in this kind of assay, due to accumulation in sediment. Cr acts on the enzymes that catalyze proteins responsible for the metabolism (Naime and Fagundes, 2005).

The greater frequency of $\mathrm{Cu}$ detection may originate both in metallurgical industries and viticulture spread throughout the region. At Ca136, $50 \%$ of the samplings contained $\mathrm{Cu}$ above the permissible value (Mar./05: $0.023 \mathrm{mg} . \mathrm{L}^{-1}$; Mar./06: $0.012 \mathrm{mg} . \mathrm{L}^{-1}$; June/06: $0.016 \mathrm{mg} . \mathrm{L}^{-1}$; Sept./06: $0.013 \mathrm{mg} . \mathrm{L}^{-1}$; June/07: $0.025 \mathrm{mg} . \mathrm{L}^{-1}$; Sept./07: 0.012 mg.L $L^{-1}$; Dec./08: 0.010 mg.L. ${ }^{-1}$; CONAMA: $\left.0.009 \mathrm{mg} . \mathrm{L}^{-1}\right)$, it should be considered that this metal may affect the development of the testorganism. Li et al. (2009) say that the organisms that graze the organic detritus in sediments can ingest a lot of copper. Comparing the detection of $\mathrm{Cu}$ in the present study to another performed previously in the area (Terra et al., 2007) an elevation in the occurrence of this metal is observed. De Schamphelaere et al. (2007), in a 21-day test with D. magna, recorded that $\mathrm{Cu}$ caused an inhibition in the rate of feeding, assimilation and growth and/ or reproduction. On the other hand, Gillis et al. (2006) mention the toxicity of $\mathrm{Cu}$ to $D$. magna when remobilized from the sediment to the water column, and the importance of natural resuspension events or dredging in the availability of metals from sediment to water.

This study considered the presence of $\mathrm{Zn}$ even at values lower than those allowed in Brazilian legislation at $\mathrm{Ca} 070, \mathrm{Ca} 092, \mathrm{Ca} 136$ and $\mathrm{Ca} 245$ because it could settle and was cumulative. Thus, the values found in sediment may be higher and interfere in the biota balance. De Sachamphelaere and Janssen (2004), state that $\mathrm{Zn}$ inhibits reproduction but not growth. Although the present study does not evaluate cladoceran growth, survival and reproductive capacity were considered. The presence of $\mathrm{Zn}$, even within the standard (CONAMA: $\left.0.18 \mathrm{mg} . \mathrm{L}^{-1}\right)$ was seen to coincide with high survival and low mean reproduction at 12 points in time (Ca070: 0.032 mg.L - $^{-1}$ (Mar./05), 0.050 mg.L $\mathrm{L}^{-1}$ (June/06), 0.063 mg. $\mathrm{L}^{-1}$ (Mar./07); Ca092: 0.039 mg.L L $^{-1}$ (Mar./06), 0.069 mg.L L $^{-1}$ (Dec./08), 
0.023 mg.L $L^{-1}$ (Mar./09); Ca136: 0.054 mg.L L $^{-1}$ (Mar./05), 0.028 mg.L - $^{-1}$ June/06), 0.034 mg.L. ${ }^{-1}$ (Dec./07), 0.110 mg.L - $^{-1}$ (Dec./08), 0.046 mg.L $L^{-1}$ (Mar./09); Ca245: 0.033 mg.L $L^{-1}$ (June/06). The accumulation of this metal in sediment may have contributed to responses observed.

During this sampling period $\mathrm{Pb}$ was not regularly found and when present the values were low, different from a previous study, when it was detected at all sites during the year of 2001 (Terra et al., 2007).

Other metals researched, $\mathrm{Hg}$ and $\mathrm{Ni}$, were not detected, but the search for these two metals was based on the fact that the former is a secondary contaminant in tanneries (Nunes and Luiz, 2006) and the latter is a common pollutant in metallurgical industry effluents (Nascimento and Naime, 2009).

The low concentration of P (Mar./06 and Dec./07: $0.01 \mathrm{mg.L} \mathrm{L}^{-1}$; Sept./06: $\left.0.017 \mathrm{mg} . \mathrm{L}^{-1}\right)$ at $\mathrm{Ca} 245$ may have been a determining factor in the high mortality observed among the cladocerans. On the other hand, the presence of E. coli $(2,400 \mathrm{MPN} / 100 \mathrm{~mL})$ and $\mathrm{P}\left(0.116 \mathrm{mg} \cdot \mathrm{L}^{-1}\right.$; CONAMA: $\left.0.0500 \mathrm{mg} . \mathrm{L}^{-1}\right)$ above the quality standard, together with low mortality $(10 \%)$ and the higher reproductive activity at Ca245 (Dec./08), may have been the result of the release of $\mathrm{P}$ and $\mathrm{N}$ present in animal feces, related directly to the presence of E. coli. It is emphasized that in the month mentioned, the $\mathrm{N}$ content also related to the presence of animal wastes was higher $\left(0.232 \mathrm{mg} . \mathrm{L}^{-1}\right)$ than normally found at this site $\left(0.02 \mathrm{mg} . \mathrm{L}^{-1}\right)$, where cattle is raised.

Meat packing plants and sewage present at Ca136, account for the presence of bacteria and P. Although these parameters presented high values in some samplings, they were not enough to cause oxygen depletion or raise BOD. However, in Mar./06, a reproductive mean above the minimum level expected for pollution-free environments was observed. This may be due to the elevation of nutrients (P: $0.251 \mathrm{mg} . \mathrm{L}^{-1}$; N: $0.500 \mathrm{mg} . \mathrm{L}^{-1}$ ). The characteristics of discharges from meat packing plants are: high organic load, fat, high nitrogen and phosphorus content, besides significant contents of various salts and, sometimes, of different aromatic compounds (Pacheco, 2006). In this study, elevated values of the interfering elements were not confirmed at Ca136, although the site is influenced by this type of business. The absence of these factors at elevated values contributed to the low levels of mortality seen at the site. There is even a possibility that the presence of $\mathrm{P}\left(0.251 \mathrm{mg} . \mathrm{L}^{-1}\right)$, favored reproduction of D. magna in Mar./06. Improving the quality of this site is consistent with the inspection of establishments along the river and the growing concern and awareness among local business people who have invested in environmental quality.

Municipal sewage discharged at $\mathrm{Ca} 092$ may be responsible for the high survival of the testorganisms due to the great contribution of nutrients discharged by this source. Lourdes et al. (2006) report the substantial presence of organic matter and $\mathrm{P}$ in untreated domestic sewage. On the other hand, the excess of organic matter, $\mathrm{P}$ and an elevated temperature may induce toxic algal blooms (Lips and Lips, 2008) causing local oxygen depletion, which could interfere in organism survival. Domestic sewage may initially lead to plankton overpopulation, and then cause the death of flora and fauna due to the limitation of factors such as DO or nutrients essential to organic synthesis. Variations in this order are found at $\mathrm{Ca} 070$, where reproduction was usually below the expected average.

Previous work in the same area (Terra et al., 2007) relates toxicity variation to the different types of stress present at each site, besides the variation of the volume of water and river width, since the Cai River bed is narrower at Ca245 (20 m) and wider at $\mathrm{Ca} 070(100 \mathrm{~m})$.

Laboratory simulations of environmental conditions and the exposure of living organisms for a long time compared to their life cycle (birth to senility) has been a major tool to identify environmental damages and remedial actions. Short assays valuing only survival-related responses miss important information when the purpose is ecosystem integrity, since often areas are classified as healthy, ignoring changes in reproduction. In this study $18 \%$ of effects related to survival were observed and $95 \%$ to reproduction, considering the total of samples evaluated, supporting the need to apply long assays to evaluate environmental quality. Previous works (Nikunen, 1985; Cowgill, 1986) report that brood size was usually more sensitive information of chronic stress than was survival. According to Cowgill (1986) small brood size is indicative of stressful conditions. Besides, it should be pointed out that in environmental samples, test-organism mortality is occasional, as observed in this work, where, on few occasions, deaths of 
microcrustaceans were recorded at the beginning of the assays.

\section{Conclusions}

Although current data indicates improved quality in the Caí River, it is necessary to perform subsequent studies to trace the history of this river, learn more details about its course and most fragile regions.

\section{Acknowledgements}

This research was funded by FEPAM. The authors wish to thank of the Sampling at FEPAM, at Conselho Nacional de Desenvolvimento Científico e Tecnológico (CNPq) for the ATP-A scholarships (Processo $\left.n^{\circ} 371743 / 2009-5\right)$ given to Ilda Rosa Feiden and ATP-A (Processo no 371290/2010-4) Fabiane Lucheta, besides the Scientific Initiation scholarships (Processos no 104342/2009-9 and 108460/2009-6 granted to Silvana Pereira Gonçalves); the Fundação Estadual de Pesquisa Agropecuária (FEPAGRO) and Defesa Civil do Rio Grande do Sul (www2.defesacivil.rs.gov.br/ estatistica/pluviometro_consulta.asp) for the rainfall data. The values informed for heavy metals, physical, chemical and microbiological parameters were obtained from the FEPAM Database.

\section{References}

ANKLEY, GT., LIBER, K., CALL, DJ., MARKEE, TP., CANFIELD, TJ. and INGERSOLL, CG. 1996. A field investigation of the relationship between zinc and acid volatile sulfide concentrations in freshwater sediments. Journal of Aquatic Ecosystem Health, vol. 5, no. 4, p. 255-264. http://dx.doi.org/10.1007/ BF00662186

American Public Health Association - APHA. 2005. Standard Methods for the examination of water and wastewater. 21th ed. Washington: M.A.H. Franson.

Associaçẫo Brasileira de Normas Técnicas - ABNT. 2004. NBR 12713. Ecotoxicologia aquática - Toxicidade aguda - Método de ensaio com Daphnia spp. (Cladocera, crustacea). Rio de Janeiro: ABNT.

BALLANTINE, D., WALLING, DE. and LEEKS, GJL. 2009. Mobilisation and transport of sedimentassociated phosphorus by surface runoff. Water, Air, \& Soil Pollution, vol. 196, p. 311-320. http://dx.doi. org/10.1007/s11270-008-9778-9

BARATA, C., MARKICH, SJ., BAIRD, DJ. and SOARES, AMVM. 2002. The relative importance of water and food as cadmium sources to Daphnia magna Straus. Aquatic Toxicology, vol. 61, p. 143-154. http://dx.doi.org/10.1016/S0166-445X(02)00052-8
BECKER, C. and BOERSMA, M. 2005. Differential effects of phosphorus and fatty acids on Daphnia magna growth and reproduction. Limnology and Oceanography, vol. 50, no. 1, p. 388-397. http:// dx.doi.org/10.4319/lo.2005.50.1.0388

BURTON JUNIOR, GA. 1992. Plankton, Macrophyte, Fish and Amphibian Toxicity Testing of Freshwater Sediments. In BURTON JR, GA., ed. Sediment toxicity assessment. Boca Raton, Florida: Lewis Publishers, p. 167-182.

CHEN, YJ., WU, SC., LEE, BS. and HUNG, CC. 2006. Behavior of storm-induced suspension interflow in subtropical Feitsui Reservoir, Taiwan. Limnology and Oceanography, vol. 51, no. 2, p. 1125-1133. http:// dx.doi.org/10.4319/lo.2006.51.2.1125

Brasil. Ministério do Meio Ambiente. Conselho Nacional do Meio Ambiente - CONAMA. Resoluçáo no. 357, de 17 de Março de 2005. Dispóe sobre a classificação dos corpos de água e diretrizes ambientais para o seu enquadramento, bem como estabelece as condiçóes e padróes de lançamento de efluentes, e dá outras providências. Diário Oficial da União, Poder Executivo, Brasília, DF, 17 abr. 2005. Available from: <http://www.mma.gov.br>. Access in: 17 abr. 2005.

COWGILL, UM., EMMEL, HW., HOPKINS, DL., TAKAHASHI, IT. and PARKER, WM. 1986. Variation in chemical composition reproductive success and body weight of Daphnia magna in relation to diet. Internationale Revue der gesamten Hydrobiologie und Hydrographie, vol. 71, no. 1, p. 79-99. http:// dx.doi.org/10.1002/iroh.19860710111

DE SCHAMPHELAERE, KAC., CANLI, M., LIERDE,VV., FORREZ, I., VANHAECKE, F. and JANSSEN, CR. 2004. Reproductive toxicity of dietary zinc to Daphnia magna. Aquatic Toxicology, vol. 70, no. 3, p. 233-244. http://dx.doi. org/10.1016/j.aquatox.2004.09.008

DE SCHAMPHELAERE, KAC. and JANSSEN, CR. 2004. Effects of chronic dietary copper exposure on growth and reproduction of Daphnia magna. Environmental Toxicology \& Chemistry, vol. 23, no. 8, p. 2038-2047. http://dx.doi.org/10.1897/03-411

DE SCHAMPHELAERE, KAC., FORREZ, I., DIERCKENS, K., SORGELOOS, P. and JANSSEN, CR. 2007. Chronic toxicity of dietary cooper to Daphnia magna. Aquatic Toxicology, vol. 81, no. 4, p. 409-418. http://dx.doi.org/10.1016/j. aquatox.2007.01.002

ELENDT, BP. and BIAS, WR. 1990. Trace nutrient deficiency in Daphnia magna cultured in standard medium for toxicity testing. Effects of the optimization of culture conditions on life history parameters of D. magna. Water Research, vol. 24, no. 9, p. 1157-1167. http://dx.doi.org/10.1016/00431354(90)90180-E

EVENS, R., DE SCHAMPHELAERE, AC. and JANSSEN, CR. 2009. The effects of dietary nickel 
exposure on growth and reproduction of Daphnia magna. Aquatic Toxicology, vol. 94, n. 2, p. 138-144. http://dx.doi.org/10.1016/j.aquatox.2009.06.011

GILLIS, PL., CHOW-FRASER, P., RANVILLE, JF., ROSS, PE. and WOOD, CM. 2005. Daphnia need to be gut-cleared too: The effect of exposure to and ingestion of metal-contaminated sediment on the gut-clearance patterns of D. magna. Aquatic Toxicology, vol. 71, p. 143-154. http://dx.doi. org/10.1016/j.aquatox.2004.10.016

GILLIS, PL., WOOD, CM., RANVILLE, JF. and CHOW-FRASER, P. 2006. Bioavailability of sediment-associated $\mathrm{Cu}$ and $\mathrm{Zn}$ to Daphnia magna. Aquatic Toxicology, vol. 77, no. 4, p. 402-411. http:// dx.doi.org/10.1016/j.aquatox.2006.01.010

HAMILTON, MA., RUSSO, RC. and THURSTON, RV. 1977. Trimmed Spearman-Karber method for estimating median lethal concentrations in toxicity bioassays. Environmental Science \& Technology, vol. 11, no. 7, p. 714-719. http://dx.doi.org/10.1021/ es60130a004

HE, X. and WANG, W-X. 2007. Kinetics of phosphorus in Daphnia at different food concentrations and carbon: phosphorus ratios. Limnology and Oceanography, vol. 52, no.1, p. 395-406. http:// dx.doi.org/10.4319/lo.2007.52.1.0395

HE, X. and WANG, W-X. 2008. Stoichiometric regulation of carbon and phosphorus in P. deficient Daphnia magna. Limnology and Oceanography, vol. 53, no. 1, p. 244-254. http://dx.doi.org/10.4319/ lo.2008.53.1.0244

INGERSOLL, CG., ANKLEY, CDGT., BENOIT, DA., BRUNSON, EL., BURTON, GA., DWYER, FJ., HOKE, RA., LandRUM, PF., NORBERGKING, TJ. and WINGER, PV. 1995. Toxicity and bioaccumulation of sediment-associated contaminants using freshwater invertebrates: a review of methods and applications. Environmental Toxicology and Chemistry, vol. 14, no. 11, p. 1885-1894. http:// dx.doi.org/10.1002/etc.5620141110

KEEN, R. and BAILLOD, CR. 1985. Toxicity to Daphnia of the end products of wet oxidation of phenol and substituted phenols. Water Research, vol. 19, no. 6, p. 767-772. http://dx.doi.org/10.1016/00431354(85)90125-3

KÜHN, R., PATTARD, M., PERNAK, K-D. and WINTER, A. 1989, Results of the harmful effects of selected water pollutants (anilines, phenols, aliphatic compounds) to Daphnia magna. Water Research, vol. 23, no. 4, p. 495-499. http://dx.doi. org/10.1016/0043-1354(89)90141-3

LEMOS, CT., VARGAS, VMF, HENRIQUES, JAP. and MATTEVI, MS. 1994. Genotoxicity of river water under the influence of petrochemical industrial complexes. Bull. Environmental Contamination and Toxicology, vol. 52, no. 6, p. 848-855. http://dx.doi. org/10.1007/BF00200693
LI, LY., HALL, K., YUAN, Y., MATTU, G., MCCALLUM, D. and CHEN, M. 2009. Mobility and bioavailability of trace metals in the watersediment system of the highly urbanized Brunette Watershed. Water, Air, \& Soil Pollution, vol. 197, p. 249-266. http://dx.doi.org/10.1007/s11270008-9808-7

LIPS, I. and LIPS, U. 2008. Abiotic factors influencing cyanobacterial bloom development in the Gulf of Finland (Baltic Sea). Hydrobiologia, vol. 614, no. 1, p. 133-140. http://dx.doi.org/10.1007/s10750008-9449-2

LIU, X-J., NI, I-H. and WANG, W-X. 2002. Trophic transfer of heavy metals from freshwater zooplankton Daphnia magna to zebrafich Danio rerio. Water Research, vol. 36, no. 18, p. 4563-4569. http://dx.doi. org/10.1016/S0043-1354(02)00180-X

LOURDES, APS., SOARES, AA., MATOS, AT., CECON, PR. and PEREIRA, OG. 2006. Remoção de fósforo em sistema de tratamento de esgoto doméstico, por escoamento superficial. Revista Brasileira de Engenharia Agricola e Ambiental, vol. 10, no. 3, p. 706-714. http://dx.doi.org/10.1590/S141543662006000300025

NAIME, R. and FAGUNDES, RS. 2005. Controle da qualidade da água do arroio Portão, Portão, RS. Pesquisas em Geociências, vol. 32, no. 1, p. 27-35.

NASCIMENTO, CA. and NAIME, R. 2009. Panorama do uso, distribuição e contaminação das águas superficiais no Arroio Pampa na bacia do Rio dos Sinos. Estudos Tecnológicos, vol. 5, no. 1, p. 101-120. doi:10.4013/ete.2009.51.08

NEBEKER, AV., CAIRNS, MA., GAKSTATTER, JH., MALUEG, KW., SCHUYTEMA, GS. and KRANCZYK, DF. 1984. Biological methods for determining toxicity of contaminated freshwater sediments to invertebrates. Environmental Toxicology \& Chemistry, vol. 3, p. 617-630. http://dx.doi. org/10.1002/etc.5620030412

NIKUNEN, E. 1985. Toxic impact of effluents from petrochemical industry. Ecotoxicology and Environmental Safety, vol. 9, p. 84-91. http://dx.doi. org/10.1016/0147-6513(85)90038-7

NUNES, LPM. and LUIZ, JG. 2006. Caracterização geoeletrica de área de curtume localizada no distrito industrial de Icoaraci, Belém - Pará. Revista Brasileira de Geofisica, vol. 24, no. 4, p. 467-481.

PACHECO, JW. 2006. Guia técnico ambiental de frigorificos: industrialização de carnes (bovinas e suínas). São Paulo: CETESB. 85 p.

REIS, A., PARKER, A. and ALENCOÃO, A. 2010. Avaliaçáo da qualidade de sedimento $s$ em rios de montanha: um caso de estudo no norte de Portugal. Associação Portuguesa dos Recursos Hidricos, vol. 31, no. 1 , p. 87-97. 
RODRIGUES, MLK. and FORMOSO, MLL. 2006. Heavy metals in recent sediments and bottom - fish under the influence of tanneries in South Brazil. Water, Air, \& Soil Pollution, vol. 176, p. 307-327. http://dx.doi.org/10.1007/s11270-006-9170-6

SUEDEL, BC., DEAVER, E. and RODGER JUNIOR, JH. 1996. Experimental factors that may affect toxicity of aqueous and sediment-bound copper to freshwater organisms. Archives of Environmental Contamination and Toxicology, vol. 30, p. 40-46. http://dx.doi.org/10.1007/BF00211327

TERRA, NR., FEIDEN, IR., FACHEL. JMG., MOREIRA, JS. and LEMKE, C. 2007. Chronic assays with Daphnia magna, 1820, Straus in sediment samples from Caí River, Rio Grande do Sul, Brazil. Acta Limnologica Brasiliensia, vol. 19, no. 1, p. 31-39.

TERRA, NR. and FEIDEN, IR. 2008. Avaliação de amostras de água do rio Caí entre os anos de 1996 e 1997 através de ensaios crônicos com Daphnia magna (Crustacea:Cladocera). Fepam em revista, vol. 2, no. 1, p. 18-25.
TWINING, BS. and FISCHER, NS. 2004. trophic transfer of trace metals from protozoa to mesozooplankton. Limnology and Oceanography, vol. 49, no. 1, p. 28-39. http://dx.doi.org/10.4319/ lo.2004.49.1.0028

VARGAS, VMF., MIGLIAVACCA, SB., HORN, RC. and TERRA, NR. 2008. Comparative temporal ecotoxicological study in a river basin influenced by petrochemical industries. Science of the Total Environment, vol. 392, no. 1, p. 79-92. http://dx.doi. org/10.1016/j.scitotenv.2007.10.043

WANG, Z-S., KONG, H-N. and WU, D-Y. 2007. Reproductive toxicity of dietary copper to a saltwater cladoceran, Moina monogolica daday. Environmental Toxicology \& Chemistry, vol. 26, no. 1, p. 126-131. http://dx.doi.org/10.1897/06-216R1.1

YU, RQ. and WANG, WX. 2002. Trace metal assimilation and release budget in Daphnia magna. Limnology and Oceanography, vol. 47, no. 2, p. 495-504. http:// dx.doi.org/10.4319/lo.2002.47.2.0495

Received: 29 November 2010 Accepted: 12 June 2011 